\title{
Article
}

\section{Two User-Friendly Molecular Markers Developed for the Identification of Hybrid Lethality Genes in Brassica oleracea}

\author{
Zhiliang Xiao, Congcong Kong, Fengqing Han, Limei Yang, Mu Zhuang, Yangyong Zhang, Yong Wang, Jialei Ji, \\ Zhansheng Li $\mathbb{D}$, Zhiyuan Fang * and Honghao Lv *i)
}

Citation: Xiao, Z.; Kong, C.; Han, F.; Yang, L.; Zhuang, M.; Zhang, Y.; Wang, Y.; Ji, J.; Li, Z.; Fang, Z.; et al. Two User-Friendly Molecular Markers Developed for the Identification of Hybrid Lethality Genes in Brassica oleracea. Agronomy 2021, 11, 982. https://doi.org/ 10.3390/agronomy11050982

Academic Editors: Xanthopoulou Aliki, Mellidou Ifigeneia and Georgia Tanou

Received: 15 April 2021

Accepted: 8 May 2021

Published: 14 May 2021

Publisher's Note: MDPI stays neutral with regard to jurisdictional claims in published maps and institutional affiliations.

Copyright: (c) 2021 by the authors. Licensee MDPI, Basel, Switzerland. This article is an open access article distributed under the terms and conditions of the Creative Commons Attribution (CC BY) license (https:// creativecommons.org/licenses/by/ $4.0 /)$.
Institute of Vegetables and Flowers, Chinese Academy of Agricultural Sciences, No. 12 Zhongguancun South Street, Beijing 100081, China; 13051379638@163.com (Z.X.); kongcongcong@caas.cn (C.K.); hanfengqing@caas.cn (F.H.); yanglimei@caas.cn (L.Y.); zhuangmu@caas.cn (M.Z.); zhangyangyong@163.com (Y.Z.); wangyong@163.com (Y.W.); jijialei@caas.cn (J.J.); lizhansheng@caas.cn (Z.L.) * Correspondence: fangzhiyuan@caas.cn (Z.F.); lvhonghao@caas.cn (H.L.); Tel.: +010-82108756 (H.L.)

\begin{abstract}
Cabbage (Brassica oleracea) is an important vegetable crop that is cultivated worldwide. Previously, we reported the identification of two dominant complementary hybrid lethality (HL) genes in cabbage that could result in the death of hybrids. To avoid such losses in the breeding process, we attempted to develop molecular markers to identify HL lines. Among 54 previous mapping markers closely linked to BoHL1 or BoHL2, only six markers for BoHL2 were available in eight cabbage lines (two BoHL1 lines; three BoHL2 lines; three lines without BoHL); however, they were neither universal nor user-friendly in more inbred lines. To develop more accurate markers, these cabbage lines were resequenced at an $\sim 20 \times$ depth to obtain more nucleotide variations in the mapping regions. Then, an InDel in BoHL1 and a single-nucleotide polymorphism (SNP) in BoHL2 were identified, and the corresponding InDel marker MBoHL1 and the competitive allele-specific PCR (KASP) marker KBoHL2 were developed and showed 100\% accuracy in eight inbred lines. Moreover, we identified 138 cabbage lines using the two markers, among which one inbred line carried BoHL1 and 11 inbred lines carried BoHL2. All of the lethal line genotypes obtained with the two markers matched the phenotype. Two markers were highly reliable for the rapid identification of HL genes in cabbage.
\end{abstract}

Keywords: hybrid lethality; Brassica oleracea; breeding; InDel marker; KASP marker

\section{Introduction}

Cabbage (Brassica oleracea L. var. capitata), a cole crop species, is a vegetable of worldwide economic importance due to its strong resistance, wide adaptability, favorable taste and health-related value $[1,2]$. Currently, compared with traditional varieties, most commercial cabbage cultivars are first-generation hybrids with strong heterosis (hybrid vigor) that are widely used in cabbage production [3,4].

Heterosis is defined as the phenomenon that the progeny of diverse varieties of a species or crosses between species exhibit greater biomass, development speeds, and fertility than both parents. The greater the differences in the genetic relationships of the parents, the greater the advantages of the relative traits that can potentially complement each other. Heterosis is used to improve yield, uniformity, and vigor and is exploited in the breeding of corn, sorghum, rice, sugar beet, onion, spinach, sunflower, broccoli, and hemp, among others [5-10].

Hybrids do not necessarily exhibit superiority or vigor but sometimes show weakness or even death, resulting in unexpected losses during the breeding process. Hybrid weakness or lethality has been reported in important crops, such as Arabidopsis, lettuce, rice, ginseng, bean, mimulus, cotton, potato, and tomato [11-18]. Additionally, in 2016, we reported the identification of hybrid lethality (HL) in cabbage that hinders the exploitation of heterosis and causes economic losses [19]. HL is a type of reproductive segregation that 
occurs after mating or fertilization and causes F1 hybrid death. Incompatibility of parental genes or chromosomes result in decreases in the viability and fertility of interspecific hybrids [20,21]. Incompatibilities in internal genetic factors cause hybrid weakness/necrosis, breakdown, sterility, and unviability. In other words, HL is a type of hybrid weakness, in contrast to heterosis.

Molecular marker technology has been widely used as a valuable tool in molecular biology research, including the analysis of genetic diversity, prediction of heterosis, identification of germplasms, gene mapping, and marker-assisted selection breeding [22-24]. There are dozens of different molecular markers, such as random amplified polymorphic DNA (RAPD), sequence-characterized amplified region (SCAR), simple sequence repeat (SSR), insertion-deletion (InDel) and competitive allele-specific PCR (KASP) markers. According to the methods for detecting DNA polymorphisms, molecular markers can be divided into four categories: (1) fragment length polymorphisms (RFLPs), whose detection is based on Southern hybridization; (2) RAPD, SSR, sequence-related amplified polymorphism (SRAP), and inter simple sequence repeat (ISSR) markers, detected based on polymerase chain reaction (PCR); (3) amplified fragment length polymorphisms (AFLPs) and Cardiac Arrhythmia Pilot Study (CAPS) markers, detected based on a combination of PCR and restriction enzyme digestion technology; and (4) the recent ones: InDel, single-nucleotide polymorphism (SNP), and KASP molecular markers. Molecular marker technology provides one of the most important auxiliary methods for genetic breeding and represents a powerful auxiliary approach for selecting and cultivating new cabbage cultivars that possess multiple superior traits. A number of molecular markers for cabbage have been developed and successfully applied for cabbage breeding, such as the SSR marker Frg13 for cabbage Fusarium wilt resistance [25,26], the InDel markers BoID0709 and BoID0992 associated with self-compatibility [27], the Rfo marker BnRFO [28,29], and the KASP marker K13 and the SCAR marker ST11 900 for dominant genic male sterility [30,31].

We have previously reported the identification of HL in cabbage [19]. Genetic analyses revealed that HL in cabbage was controlled by two complementary dominant genes, BoHL1 and BoHL2, which were then mapped to chromosomes $\mathrm{C} 1$ and $\mathrm{C} 4$, respectively [32]. In hybrid breeding, lethal cabbage hybrid combinations cannot be predicted, and their appearance inevitably causes economic losses. Therefore, it is necessary to identify materials carrying HL genes by using high-efficiency and user-friendly diagnostic molecular markers. In the current study, we developed molecular markers based on the whole-genome resequencing data of a series of inbred lines to identify cabbage lines carrying HL genes, which were further validated in 138 accessions to validate their reliability.

\section{Materials and Methods}

\subsection{Plant Materials}

Eight cabbage lines were used in our study: two BoHL1 lines (09-211 and 11-204) and three BoHL2 lines (09-222, 10-260 and 11-176), in which the hybrid plants of the BoHL1 lines and $B o H L 2$ lines exhibited 100\% seedling mortality at a late stage of growth, and three control lines (87-534, 96-100 and 01-20) without the HL genes. Additionally, 138 Brassica crop species (106 cabbage lines, 10 broccoli lines, 11 Chinese cabbage lines and 11 Chinese kale lines) were identified and used to validate the specific markers. All plant materials were provided by the Cabbage and Broccoli Research Group, Institute of Vegetables and Flowers, Chinese Academy of Agricultural Sciences (IVF-CAAS).

\subsection{Primer Design}

First, we attempted to identify user-friendly markers from the fine mapping markers of BoHL1 and BoHL2 in the eight cabbage lines. We identified one SSR marker and 28 InDel markers for BoHL1 and 27 InDel markers for BoHL2 that have been used for the fine mapping of HL genes [19,32]. Furthermore, all eight cabbage lines were resequenced to an $\sim 20 \times$ depth to obtain additional nucleotide variations, which were deposited in the NCBI Sequence Read Archive (SRA) under BioSample accessions (SAMN06841129- 
30, SAMN17385836-47). For BoHL1, we searched the genomic region in the BoHL1 fine mapping region for nucleotide variations (SNPs, InDels and structural variants (SVs)) between the BoHL1 lines and no-BoHL1 lines (BoHL2 lines and three control lines); using the same strategy, we searched nucleotide variations between the BoHL2 lines and noBoHL2 lines (BoHL1 lines and three control lines) from the fine mapping region of BoHL2. InDels $\geq 3$ bp long and SVs were used to design InDel markers; InDels $\leq 2$ bp long and SNPs were selected to design KASP markers following the PolyMarker pipeline). The primers were designed with Premier 5 (Premier Biosoft International, Palo Alto, CA, USA). Nucleotide variations associated with the markers were verified by Sanger sequencing, and sequence alignment was conducted with DNAman.

\subsection{Genotyping}

The genomic DNA of all cabbage lines was extracted from young leaves according to the modified CTAB protocol. The concentration of DNA was determined using an ND-1000 system (NanoDrop Technologies, Inc. Wilmington, DE, USA), and the DNA was then diluted to $40-50 \mathrm{ng} / \mu \mathrm{L}$. For the InDel markers, PCR was performed using $2 \times$ Taq Master Mix (Vazyme, Nanjing, China). The reaction system and program followed the manufacturer's instructions. The PCR-amplified products were checked by $1 \%$ agarose gel electrophoresis $(150 \mathrm{~V})$ and subjected to sequencing. The KASP assay was performed following the protocol of LGC Genomics (Berlin, Germany), as reported previously [33]. An Applied Biosystems Viia 7 real-time PCR system (Applied Biosystems, Foster City, CA, USA) was used to detect allele-specific fluorescence, and the 122 genotypes were called with Viia 7 software, v1.0. To analyze the phenotypes and genotypes, BoHL1 genotypes and normal genotypes were recorded as "aa" and "bb", respectively; BoHL2 genotypes and normal genotypes were recorded as "cc" and " $\mathrm{dd}^{\text {", }}$, respectively; and heterozygous genotypes and other genotypes were recorded as " $\mathrm{h}$ " and "ee", respectively.

\subsection{Phenotyping}

The cabbage lines identified by using the molecular markers were crossed with 09-211 or 09-222. The $\mathrm{F}_{1}$ seeds will be sown in the field and observed the growth of the seedlings. Lethal symptoms in cabbage performance, e.g., retarded growth, wilting, and chlorosis, gradually appeared at approximately 30 days after germination. The positive control HL cross combination was 09-211 $\times 09-222$, and the negative control cross combination was $09-211 \times 87-534$.

\section{Results}

\subsection{Identification of Linkage Markers from the Fine-Mapping Primers}

First, we identified the primers used for the fine mapping of HL genes in the eight cabbage lines, and the results are shown in Table 1. Among the markers linked to the BoHL1 gene, none of the twenty-nine markers showed $100 \%$ accuracy in the eight cabbage lines, and eight markers presented $87.5 \%$ accuracy. These eight markers all showed genotypes that did not match the phenotype of cabbage lines 11-204. The identification of $50 \%$ false positives in two BoHL1 lines indicated that these could not be used for identifying HL. Among the markers linked to BoHL2, six InDel markers, HL205, HL230, L27, L237, L43 and L411, showed 100\% accuracy in distinguishing the eight cabbage lines (Figure 1), and six markers showed 87.5\% accuracy (HL202, HL204, HL207, HL208, HL209 and HL235). Then, four InDel markers (HL230, L27, HL209 and L237) were used to identify 138 inbred lines, and the results are shown in Table S4. We found that $89.8 \%(124 / 138)$ of the inbred lines showed consistent genotypes at the four InDel markers, suggesting that the four markers presented relatively consistent evaluation results. Among these cabbage lines, 13 showed the same genotypes as the BoHL2 lines, including G4, G11, G18, G29, G43, G73, G81, G87, G90, G91, G92, G93 and G95, suggesting that these cabbage lines might carry the BoHL1 gene. However, some of the inbred lines showed different genotypes for HL230, L27, HL209 and L237, such as G67 (dd; dd; h; dd), P4 (e; dd; dd; dd), J7 (dd; dd; e; dd), QH11 
(dd; dd; dd; e) and BC6 (e; dd; dd; dd). Moreover, some markers exhibited nonspecific amplification in certain lines, showing no amplified bands (G46, G70 for HL230; G62 for L237) or different bands (G70, G75, J7 and Y2 for HL209; P4, BC6 for HL230). These results indicated that these markers are universal in inbred lines with different backgrounds and that more user-friendly molecular markers for HL genes should be developed.

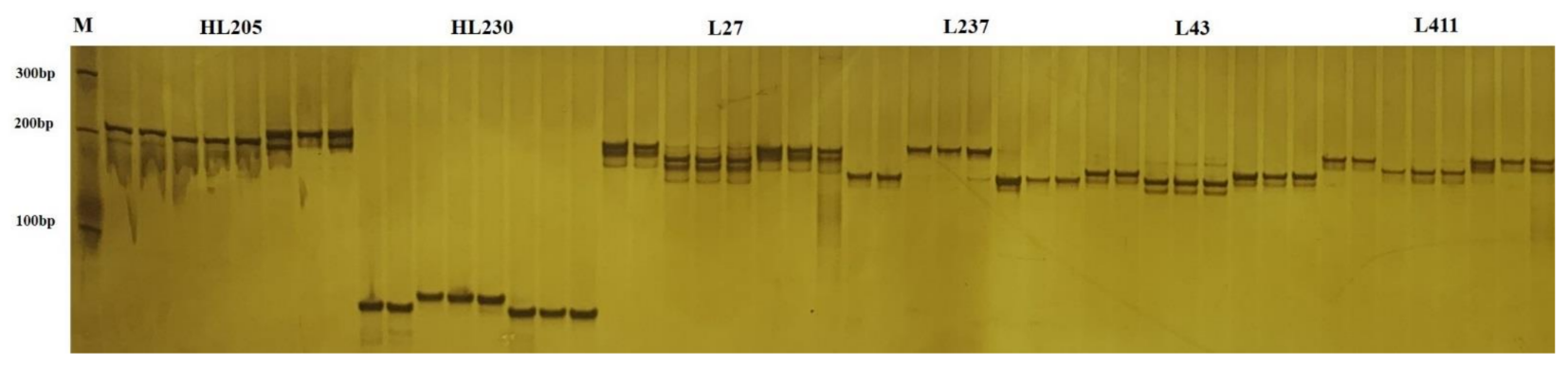

Figure 1. Detection of eight cabbage lines by using six BoHL2 markers. Six InDel markers (HL205, HL230, L27, L237, L43 and L411) showed $100 \%$ accuracy in distinguishing the eight cabbage lines.

\subsection{Development of the InDel Marker MBoHL1 Associated with BoHL1}

The resequencing data of the eight cabbage lines were mapped to the TO1000 cabbage reference genome (http:/ / plants.ensembl.org/Brassica_oleracea/Info/Index (accessed on 20 September 2020)). According to our previous study, BoHL1 and BoHL2 were located on chromosome C1 (42.79-42.90 Mb) and chromosome C4 (46.33-46.40 Mb), respectively [32]. In the BoHL1 mapping location, seven nucleotide variations (4 SNPs, 2 InDels and 1 SV) were identified in BoHL1 lines in comparison with the no-BoHL1 lines (Table S1). The SV insert (CCCATTATGGCCGGTCCTGGGCAAAGCCTAACGAAACATTGGCGTTAGGCCTCCAAAAATTTTGGAAAAAATTACATAGAAAAAAGCTCCCAAAATTTGTTTTTTAG GCCCCTAAATTTACAAAAAATTTTTTAGCTGAAATTTTTTAAAAACCGCCTGCAGCCCCCTAAATCTCAGGGCCGGCCCCGAGTTAC) was confirmed by Sanger sequencing, and then the InDel marker MBoHL1 was developed to amplify the sequence. The MBoHL1 sequences were MBoHL1F ( $5^{\prime}$ to $\left.3^{\prime}\right)$ : TAAACAAGGCTGGATAACAATAC and MBoHL1R $\left(5^{\prime}\right.$ to $\left.3^{\prime}\right)$ : TCACCGGTCTGCTTCTTGAC. The graph of the agar gel results showed that the lanes containing the amplification products of the BoHL1 lines were approximately $200 \mathrm{bp}$ longer than the lanes of the other lines, and the alignment results also suggested that the SV carrying the 195-bp insert was only present in the BoHL1 lines (Figure 2). Then, the InDel marker MBoHL1, which showed 100\% accuracy in the eight lines, was developed and applied to identify whether more inbred lines carried BoHL1.

\subsection{Development of the KASP Marker KBoHL2 Associated with BoHL2}

No common nucleotide variations were identified in the BoHL2 lines in the region containing BoHL2 (46.33-46.40 Mb). Hence, we expanded the search for mutations to $50 \mathrm{~kb}$ up- and downstream of the BoHL2 region, and two SNPs and two InDels were identified in the BoHL2 lines in comparison with the no-BoHL2 lines (Table S2). We chose two SNP mutations: SNP1, a $\mathrm{T}$ to $\mathrm{C}$ in $46,333,244$, and SNP2, a G to A in $46,412,513$. Two primers were designed for confirmation by Sanger sequencing. However, the sequencing results produced incorrectness for SNP2: the G to A mutation at 11-176 was not present. The sequencing results for SNP1 (46333244) confirmed its accuracy in the eight lines, and the KASP marker KBoHL2 was then designed. The KASP primer sequences were Primer_Allele X ( $5^{\prime}$ to $\left.3^{\prime}\right)$ : CTCCGGGTTTTCCCGATATCC; Primer_Allele Y $\left(5^{\prime}\right.$ to $\left.3^{\prime}\right)$ : TACTCCGGGTTTTCCCGATATCT; Primer_Common ( $5^{\prime}$ to $\left.3^{\prime}\right)$ : GCCTGGACGATGGTAGCTCGAA. We evaluated the eight cabbage lines to assess the applicability and accuracy of KBoHL2, and genotyping with KBoHL2 showed 100\% accuracy in the eight lines ( $\mathrm{T} / \mathrm{T}$ allele for three BoHL2 lines and $\mathrm{C} / \mathrm{C}$ allele for five no-BoHL2 lines) (Figure 3), indicating that KBoHL2 was a useful marker for the BoHL2 gene. 
Table 1. Phenotyping of 54 pairs of fine mapping markers in eight cabbage lines. BoHL1 genotypes, normal genotypes, heterozygous genotypes, other genotypes and no amplified bands were recorded as "aa", “bb”, “ $\mathrm{h}$ ”, “cc" and "no", respectively.

\begin{tabular}{|c|c|c|c|c|c|c|c|c|c|c|}
\hline \multirow{2}{*}{ Phenotyping } & \multirow{2}{*}{ Primers } & \multirow{2}{*}{$\begin{array}{l}\text { Physical } \\
\text { Location }\end{array}$} & \multicolumn{2}{|c|}{ BoHL1 Lines } & \multicolumn{3}{|c|}{ BoHL2 Lines } & \multicolumn{3}{|c|}{ Control Lines } \\
\hline & & & 09-211 & 11-204 & $09-222$ & $10-260$ & $11-176$ & $87-534$ & $96-100$ & $01-20$ \\
\hline \multirow{29}{*}{ BoHL1 } & LTSSR44 & C1: 23318181 & aa & aа & $\mathrm{u}$ & $\mathrm{bb}$ & $\mathrm{bb}$ & $\mathrm{u}$ & $\mathrm{bb}$ & $\mathrm{bb}$ \\
\hline & HL001 & C1: 39731894 & aa & $\mathrm{h}$ & $\mathrm{bb}$ & $\mathrm{bb}$ & $\mathrm{bb}$ & $\mathrm{bb}$ & $\mathrm{bb}$ & $\mathrm{bb}$ \\
\hline & HL012 & C1: 39968608 & aа & $\mathrm{h}$ & aa & $\mathrm{bb}$ & aа & $\mathrm{bb}$ & $\mathrm{bb}$ & $\mathrm{bb}$ \\
\hline & HL028 & C1: 40360684 & aa & aа & aa & $\mathrm{bb}$ & $\mathrm{bb}$ & $\mathrm{bb}$ & $\mathrm{bb}$ & $\mathrm{bb}$ \\
\hline & D105 & C1: 40363439 & aa & $\mathrm{h}$ & $\mathrm{bb}$ & $\mathrm{bb}$ & $\mathrm{bb}$ & $\mathrm{bb}$ & $\mathrm{bb}$ & $\mathrm{bb}$ \\
\hline & HL032 & C1: 40373674 & aa & $\mathrm{h}$ & $\mathrm{bb}$ & $\mathrm{bb}$ & $\mathrm{bb}$ & $\mathrm{bb}$ & $\mathrm{bb}$ & $\mathrm{bb}$ \\
\hline & HL051 & C1: 41063342 & аa & $\mathrm{bb}$ & aa & $\mathrm{bb}$ & $\mathrm{bb}$ & aа & aa & $\mathrm{bb}$ \\
\hline & $\mathrm{X} 12$ & C1: 12987 & aа & $\mathrm{bb}$ & aа & aа & aа & aa & aа & $\mathrm{bb}$ \\
\hline & $\mathrm{X} 29$ & C1: 10008626 & aa & $\mathrm{bb}$ & $\mathrm{bb}$ & $\mathrm{bb}$ & $\mathrm{bb}$ & $\mathrm{bb}$ & $\mathrm{bb}$ & $\mathrm{bb}$ \\
\hline & X32 & C1: 10010120 & aа & $\mathrm{bb}$ & $\mathrm{bb}$ & $\mathrm{bb}$ & $\mathrm{bb}$ & $\mathrm{bb}$ & $\mathrm{bb}$ & $\mathrm{bb}$ \\
\hline & $\mathrm{X} 37$ & C1: 10012611 & aa & $\mathrm{bb}$ & aa & $\mathrm{bb}$ & aa & аa & $\mathrm{bb}$ & $\mathrm{bb}$ \\
\hline & X300 & C1: 41434284 & aа & $\mathrm{h}$ & aa & $\mathrm{CC}$ & $\mathrm{d}$ & aа & $\mathrm{bb}$ & $\mathrm{CC}$ \\
\hline & X247 & C1: 42584137 & aа & $\mathrm{bb}$ & aa & $\mathrm{bb}$ & $\mathrm{bb}$ & aа & $\mathrm{bb}$ & $\mathrm{bb}$ \\
\hline & X501 & C1: 42670038 & aа & $\mathrm{bb}$ & aа & aa & $\mathrm{bb}$ & aа & $\mathrm{bb}$ & $\mathrm{bb}$ \\
\hline & X582 & C1: 42772807 & aa & $\mathrm{bb}$ & aa & $\mathrm{bb}$ & aа & aа & aа & $\mathrm{bb}$ \\
\hline & X584 & C1: 42774048 & aa & $\mathrm{bb}$ & aa & aa & aa & aa & aa & aa \\
\hline & X585 & C1: 42774887 & aа & $\mathrm{h}$ & aa & $\mathrm{bb}$ & aа & aа & aa & $\mathrm{bb}$ \\
\hline & X590 & C1: 42779091 & aa & $\mathrm{h}$ & aa & $\mathrm{bb}$ & aa & aа & aa & $\mathrm{bb}$ \\
\hline & X594 & C1: 42793815 & aa & $\mathrm{h}$ & aa & $\mathrm{bb}$ & aa & aа & aa & $\mathrm{bb}$ \\
\hline & X538 & C1: 42864334 & aa & $\mathrm{CC}$ & $\mathrm{bb}$ & $\mathrm{bb}$ & aа & $\mathrm{CC}$ & aа & aa \\
\hline & X621 & C1: 42873488 & aа & $\mathrm{bb}$ & aa & $\mathrm{bb}$ & $\mathrm{bb}$ & $\mathrm{bb}$ & $\mathrm{bb}$ & $\mathrm{bb}$ \\
\hline & $X 623$ & C1: 42874011 & aа & $\mathrm{h}$ & aа & $\mathrm{bb}$ & $\mathrm{bb}$ & $\mathrm{bb}$ & $\mathrm{bb}$ & $\mathrm{bb}$ \\
\hline & X624 & C1: 42875365 & aа & $\mathrm{h}$ & aа & $\mathrm{bb}$ & $\mathrm{u}$ & aa & $\mathrm{u}$ & $\mathrm{u}$ \\
\hline & X626 & C1: 42875871 & aа & $\mathrm{h}$ & aa & $\mathrm{bb}$ & $\mathrm{u}$ & $\mathrm{CC}$ & $\mathrm{u}$ & $\mathrm{u}$ \\
\hline & X541 & C1: 42905646 & aа & aа & $\mathrm{bb}$ & $\mathrm{bb}$ & aa & $\mathrm{bb}$ & aa & $\mathrm{bb}$ \\
\hline & X516 & C1: 42920689 & aa & $\mathrm{bb}$ & $\mathrm{bb}$ & $\mathrm{bb}$ & $\mathrm{bb}$ & $\mathrm{bb}$ & $\mathrm{bb}$ & $\mathrm{bb}$ \\
\hline & $X 422$ & C1: 42975389 & aa & $\mathrm{bb}$ & $\mathrm{bb}$ & $\mathrm{bb}$ & $\mathrm{bb}$ & $\mathrm{bb}$ & $\mathrm{bb}$ & $\mathrm{bb}$ \\
\hline & X458 & C1: 43006885 & aa & $\mathrm{bb}$ & $\mathrm{bb}$ & $\mathrm{bb}$ & $\mathrm{bb}$ & $\mathrm{bb}$ & $\mathrm{bb}$ & $\mathrm{bb}$ \\
\hline & X461 & C1: 43034544 & aa & aa & aa & $\mathrm{bb}$ & $\mathrm{bb}$ & aa & $\mathrm{bb}$ & $\mathrm{bb}$ \\
\hline \multirow{25}{*}{ BoHL2 } & HL202 & C4: 44545337 & aa & aa & $\mathrm{bb}$ & $\mathrm{bb}$ & $\mathrm{bb}$ & $\mathrm{bb}$ & aa & aa \\
\hline & HL204 & C4: 44603328 & aа & aа & $\mathrm{bb}$ & $\mathrm{bb}$ & $\mathrm{bb}$ & $\mathrm{bb}$ & aа & aa \\
\hline & HL205 & C4:44622468 & aа & aа & $\mathrm{bb}$ & $\mathrm{bb}$ & $\mathrm{bb}$ & аa & aа & aa \\
\hline & HL207 & C4:45681773 & aа & aа & $\mathrm{bb}$ & $\mathrm{bb}$ & aа & aа & aa & aа \\
\hline & HL208 & C4:45758544 & aa & $\mathrm{bb}$ & $\mathrm{bb}$ & $\mathrm{bb}$ & $\mathrm{bb}$ & aa & aa & aa \\
\hline & HL209 & C4:45763718 & aа & $\mathrm{bb}$ & $\mathrm{bb}$ & $\mathrm{bb}$ & $\mathrm{bb}$ & aa & aa & aa \\
\hline & HL213 & C4:45955493 & aа & aа & $\mathrm{bb}$ & $\mathrm{bb}$ & aa & $\mathrm{bb}$ & aа & aa \\
\hline & HL223 & C4:46159416 & aа & $\mathrm{bb}$ & aa & aa & aa & $\mathrm{bb}$ & aa & aа \\
\hline & HL227 & C4:46266526 & aа & $\mathrm{h}$ & aa & aа & aа & aa & $\mathrm{bb}$ & aa \\
\hline & HL230 & C4:46320472 & aа & aа & $\mathrm{bb}$ & $\mathrm{bb}$ & $\mathrm{bb}$ & aа & aа & aa \\
\hline & HL234 & C4:46336754 & aа & $\mathrm{h}$ & $\mathrm{bb}$ & $\mathrm{bb}$ & $\mathrm{bb}$ & aа & aa & aа \\
\hline & HL235 & C4:46408921 & aa & $\mathrm{bb}$ & $\mathrm{bb}$ & $\mathrm{bb}$ & $\mathrm{bb}$ & aa & aa & $\mathrm{bb}$ \\
\hline & HL239 & C4:47534851 & aa & $\mathrm{bb}$ & $\mathrm{bb}$ & aa & $\mathrm{bb}$ & $\mathrm{bb}$ & $\mathrm{bb}$ & $\mathrm{bb}$ \\
\hline & HL249 & C4:47534851 & aа & $\mathrm{h}$ & $\mathrm{h}$ & $\mathrm{h}$ & aa & aa & aа & aa \\
\hline & HL251 & C4:47619454 & aа & $\mathrm{h}$ & $\mathrm{bb}$ & $\mathrm{bb}$ & aa & $\mathrm{bb}$ & aа & aa \\
\hline & L382 & C4:46024699 & aa & $\mathrm{bb}$ & $\mathrm{bb}$ & $\mathrm{bb}$ & aа & $\mathrm{bb}$ & $\mathrm{bb}$ & aa \\
\hline & L148 & C4:46058658 & aa & $\mathrm{bb}$ & $\mathrm{bb}$ & $\mathrm{bb}$ & $\mathrm{bb}$ & aa & $\mathrm{bb}$ & aa \\
\hline & $\mathrm{L} 27$ & C4:46162407 & aа & aа & $\mathrm{bb}$ & $\mathrm{bb}$ & $\mathrm{bb}$ & aа & aа & aa \\
\hline & L237 & C4:46289641 & aа & aа & $\mathrm{bb}$ & $\mathrm{bb}$ & $\mathrm{bb}$ & aа & aa & aа \\
\hline & $\mathrm{L} 43$ & C4:46304511 & aа & aа & $\mathrm{bb}$ & $\mathrm{bb}$ & $\mathrm{bb}$ & aа & aa & aa \\
\hline & L411 & C4:46162346 & aa & aa & $\mathrm{bb}$ & $\mathrm{bb}$ & $\mathrm{bb}$ & aа & aa & aa \\
\hline & L366 & C4:46771685 & aа & $\mathrm{CC}$ & $\mathrm{bb}$ & $\mathrm{bb}$ & aа & $\mathrm{CC}$ & aa & aа \\
\hline & $\mathrm{L} 274$ & C4:47177899 & aa & $\mathrm{CC}$ & $\mathrm{bb}$ & $\mathrm{bb}$ & aа & aа & aa & $\mathrm{CC}$ \\
\hline & L281 & $\mathrm{C} 4: 47450452$ & aа & $\mathrm{CC}$ & $\mathrm{bb}$ & $\mathrm{bb}$ & aа & aа & aa & $\mathrm{CC}$ \\
\hline & L308 & C4:52040075 & aа & $\mathrm{h}$ & aa & $\mathrm{h}$ & aа & aа & aа & aa \\
\hline
\end{tabular}




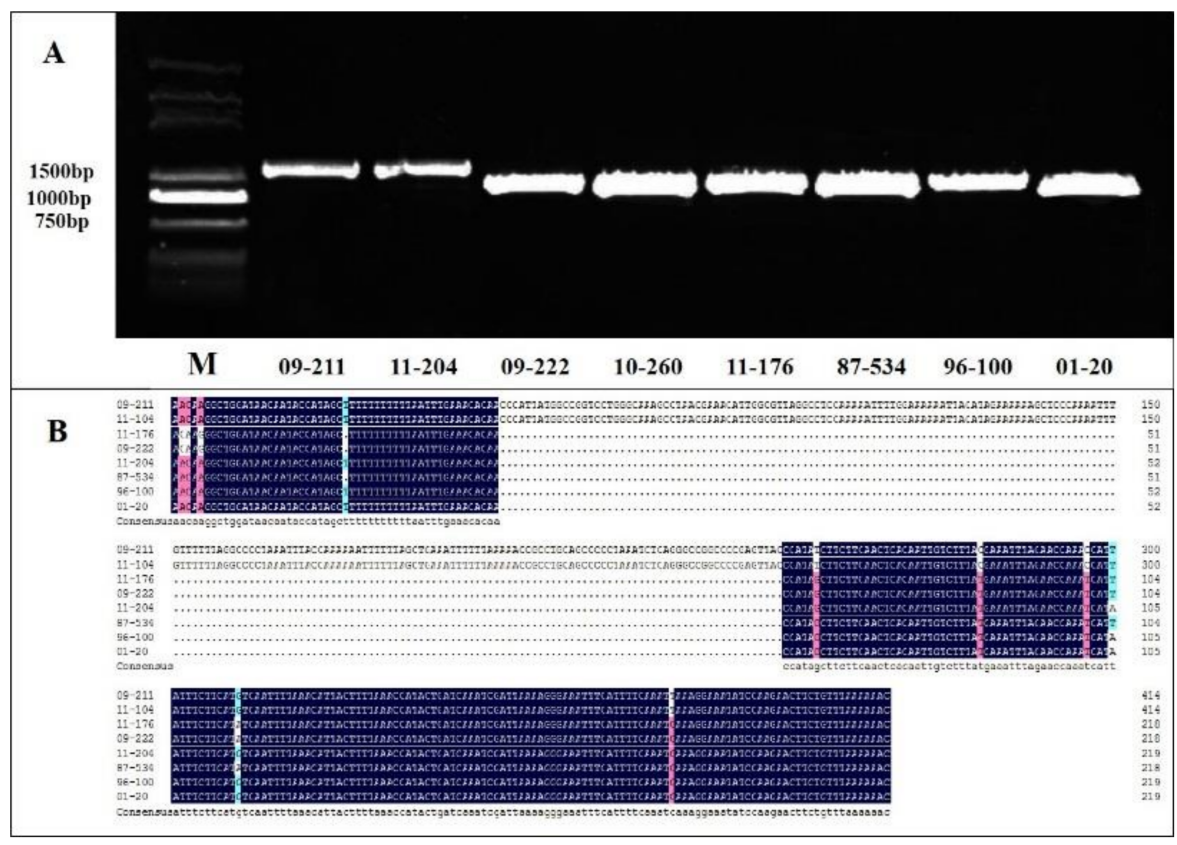

Figure 2. Detection of eight cabbage lines by using MBoHL1 and alignment results of Sanger sequencing. (A), the amplification products of the BoHL1 lines were approximately 200 bp longer than the lanes of the other lines; (B), the alignment results also suggested that the SV carrying the 195-bp insert was only present in the BoHL1 lines.
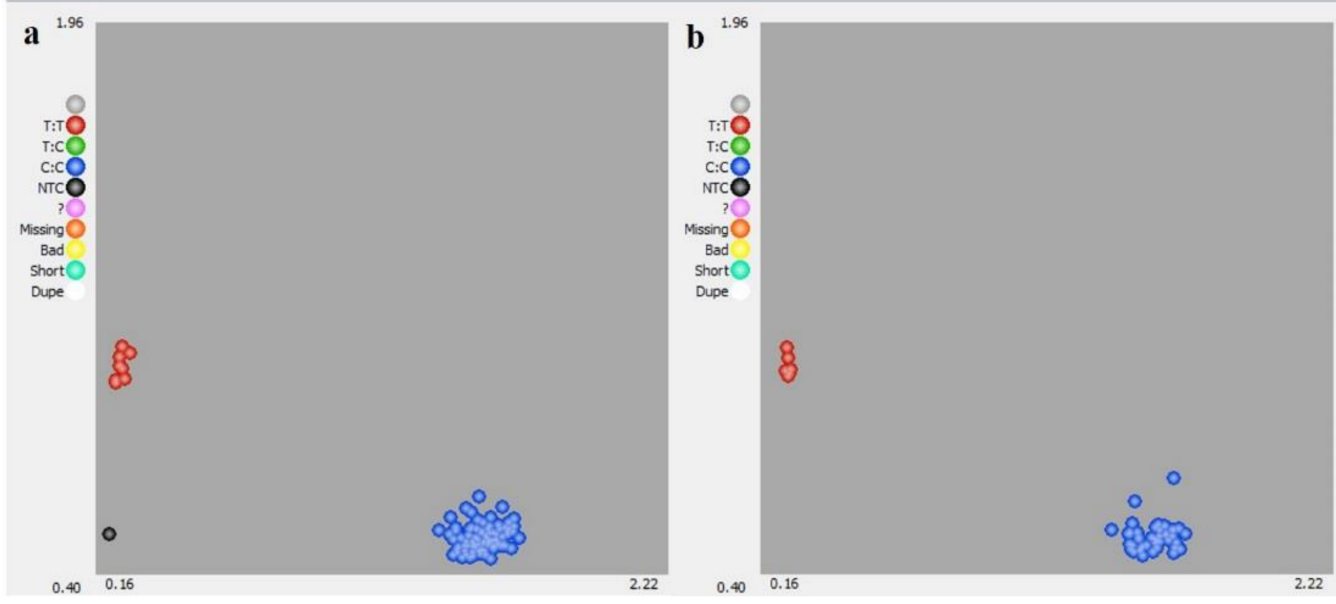

Figure 3. Genotype plot for KBoHL2 generated using the KASP assay. T/T (Red dots), genotypic results for 11 BoHL2 lines; C/C (Blue dots), genotypic results for normal lines; black dots indicate negative controls. (a), Genotype plot for 1-100 lines by KBoHL2, (b), Genotype plot for 101-138 lines by KBoHL2.

\subsection{Both MBoHL1 and KBoHL2 Showed 100\% Accuracy in Identifying HL Genes in Cabbage}

Previously, five hybrid lethal lines, including four cultivated cabbage lines (09-211, 11-204, 09-222 and 11-176) and one wild cabbage line (10-260), were discovered. To identify additional hybrid lethal lines to avoid the HL phenomenon during breeding and further confirm the reliability of our molecular markers, 138 inbred lines with different backgrounds were identified using MBoHL1 and KBoHL2. In the MBoHL1-based analysis, only one cabbage line G94 showed the same bands as the BoHL1 cabbage lines (Figure 4). In the KBoHL2-based analysis, 11 inbred lines exhibited the A/A allele, which showed the same allele with BoHL2 lines, including G4, G11, G18, G29, G43, G87, G90, G91, G92, G93 and G95 (Figure 3). Compared with the identification results of the markers HL230, L27, HL209 
and L237, two cabbage lines (G73 and G81) were not identified by KBoHL2 as carrying BoHL2 (Table S4). Above identified HL lines will be further tested using different cross combinations.

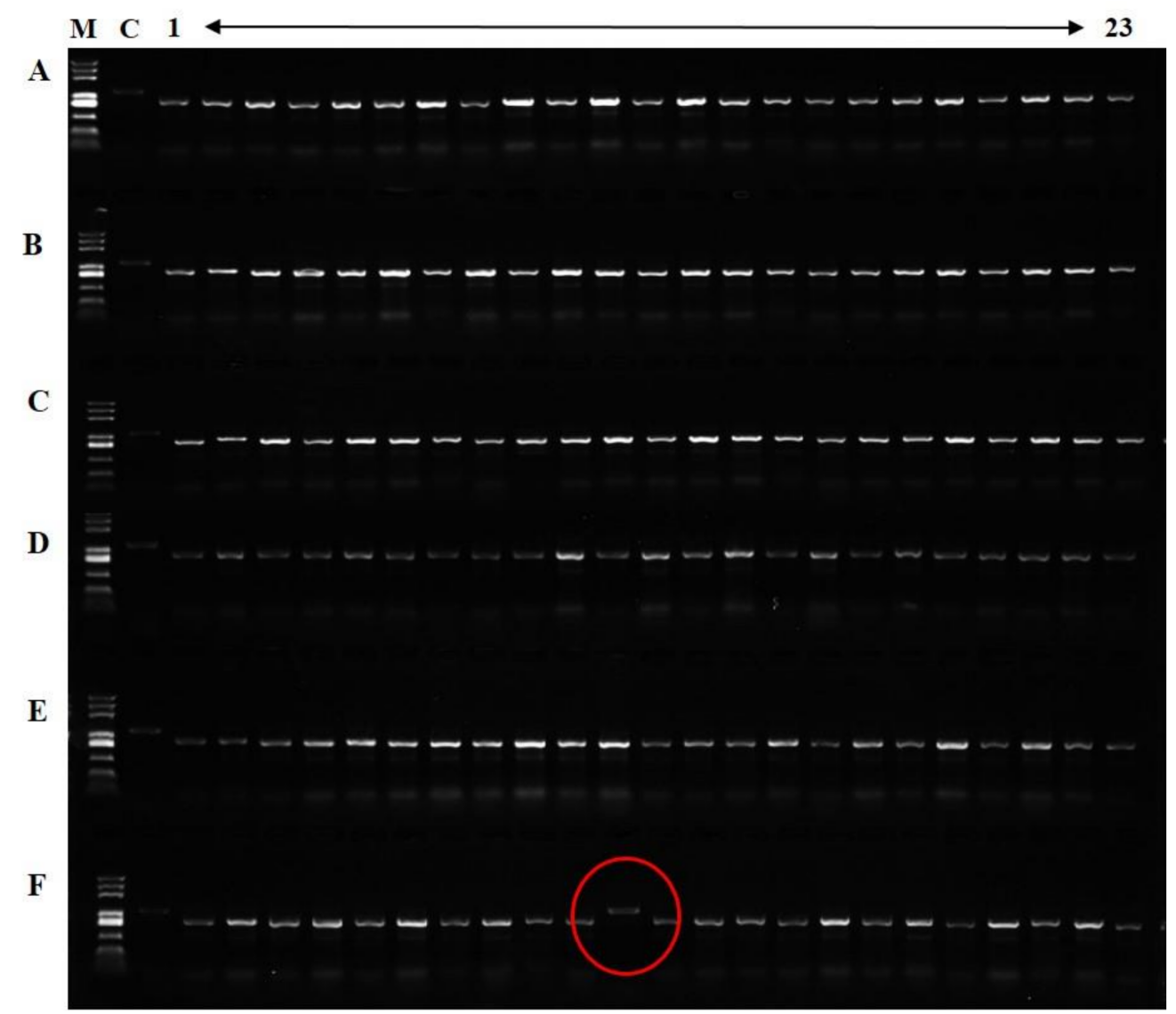

Figure 4. Detection of 138 cabbage lines by using MBoHL1. C, positive control, the amplified bands of 09-211. F11 (cabbage line G94) exhibited the same bands as the positive control (The red circle). (A) A2-A23, (B) B2-B23, (C) C2-C23, (D) D2-D23, (E) E2-E23, (F) F2-F23 represent 138 cabbage lines.

Then, 12 inbred lines identified by using MBoHL1 and KBoHL2 and other cabbage lines were crossed 09-211 and 09-222, respectively. The list of different cross combinations is shown in Table S3. All seeds exhibited a 100\% germination rate, and in the first developmental stage, they appeared normal. Some cross combinations resulted in the same lethal phenotype observed in the control hybrid lethal $F_{1}(09-211 \times 09-222)$ line, causing $100 \%$ seedling mortality (Figure 5). All of the plant lethal genotypes identified by using MBoHL1 and KBoHL2 matched the phenotyping and test crossing results, indicating that the two markers presented $100 \%$ accuracy in the rapid identification of hybrid lethal lines. However, the $F_{1}$ hybrids generated from crosses between G73 and G81 were all normal plants, suggesting that false positives were identified by the previous mapping markers HL230, L27, HL209 and L237. Thus, the BoHL1-specific InDel marker MBoHL1 and the BoHL2-specific KASP marker KBoHL2 showed 100\% accuracy and were reliable markers for the rapid identification of HL genes in cabbage. 


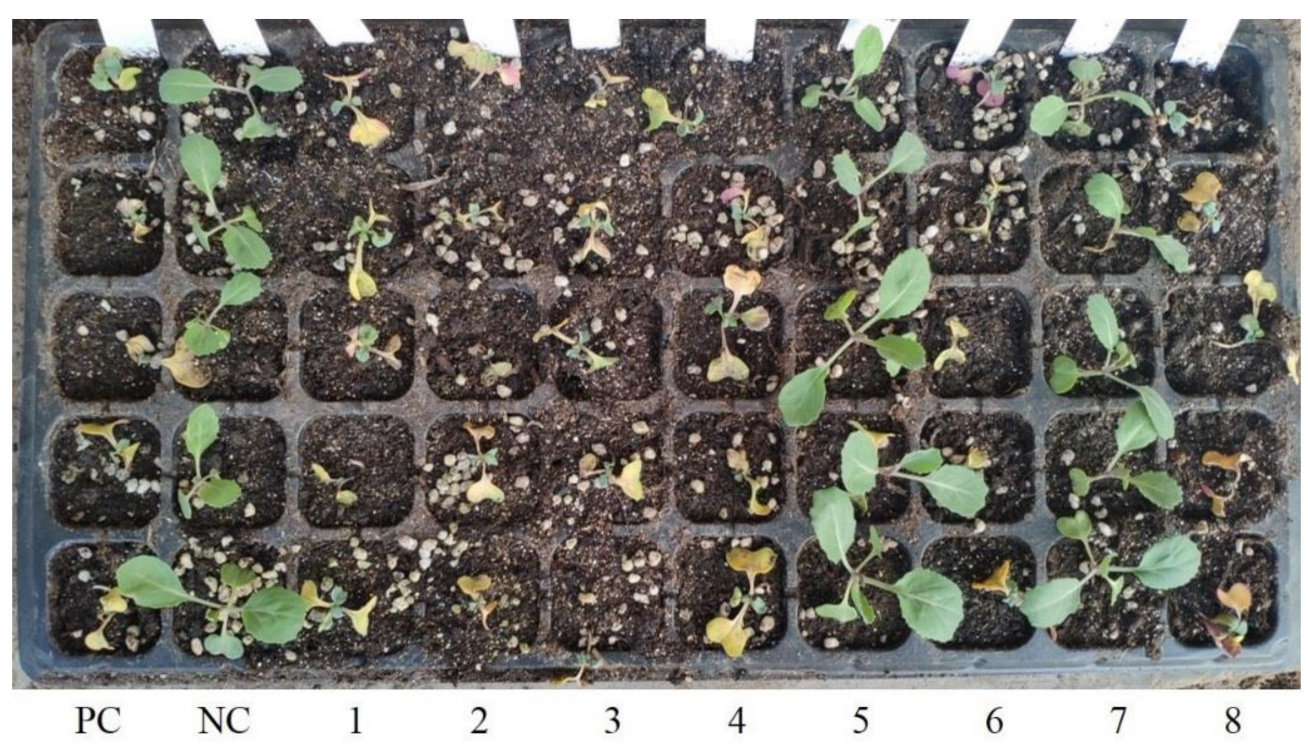

Figure 5. Phenotyping and test crossing results. PC, positive control group: hybrid lethality $\mathrm{F}_{1}$ (09-211 × 09-222); NC, negative control group: normal cross combination 09-211 × 87-534; 1, 2, 3, 4, 6 and 8 exhibited the same lethal phenotype with $100 \%$ seedling mortality; 5 and 7 appeared normal.

\section{Discussion}

\subsection{Molecular Marker Technology}

Marker-assisted selection is an important tool that is widely used in breeding and enables direct genotypic selection and effective gene polymerization through the application of specific markers associated with target characteristics. In our study, InDel markers associated with BoHL1 and KASP markers associated with BoHL2 were successfully developed. First, six fine mapping markers for BoHL2 showed $100 \%$ accuracy in the eight cabbage lines. Compared with the results obtained with KBoHL2, 11 inbred lines carrying BoHL2 genes were also identified by HL230, L27, HL209 and L237. However, two cabbage lines (G73 and G81) were identified as false positives by HL230, L27, HL209 and L237, suggesting that it is not easy to obtain user-friendly markers from these short InDel markers. InDel markers used for fine mapping should be selected to detect 3-8 bp InDels from a 100-150-bp region, which should make them sensitive to variation within the amplified region. Different background lines may show other variations within an amplified region, reducing its applicability. Moreover, two different kinds of molecular markers show unique advantages in the process of the operation. KASP markers can be used to carry out batch experiments, but such experiments require expensive equipment. InDel markers show high accuracy and stability, helping to avoid confusion in subsequent analyses due to marker specificity and complexity. Thus, it is important to choose appropriate molecular marker types. Recently, KASP markers have been successfully applied in molecular marker studies, such as the codominant KASP markers sunKASP_224 and sunKASP_225, which were developed for marker-assisted pyramiding of Sr26 with other stem rust resistance genes to achieve durable resistance in wheat [34]; M6 was homozygous for six DNA Kompetitive Allele Specific PCR (KASP) markers spanning a 224-kb region linked to Sli in Dutch germplasm; some KASP markers were developed to improve rice eating and cooking quality through marker-assisted selection to cater to the various consumer preferences, especially in Asian areas [35]. In addition, there are other key criteria for obtaining universal user-friendly markers. (1) The generation of accurate data on mutation variations is one precondition. In our study, eight cabbage lines were used as control materials to test these molecular markers along with $20 \times$ resequencing data, which provided sufficient data and sufficient inbred lines as a basis for effectively identifying mutations. It is necessary to confirm the accuracy of these mutations using Sanger sequencing because the resequencing data presented false positives (errors for SNP2 were found in the resequencing data). Han et al. 
(2019) also confirmed nucleotide variations for developing KASP markers using Sanger sequencing and obtained four $100 \%$ polymorphism markers for cabbage male sterility selection [30]. (2) Sufficient control materials with different backgrounds are needed to increase the accuracy and potential applications of the results; in the current study, we adopted a set of 138 different Brassica accessions to meet this criterion. Additionally, to evaluate the application value of the core SNP markers in rice breeding, 481 germplasms were genotyped with three functional KASP markers designed from the sequences of GBSSI, SSIIa, and Badh2, which constitute a convenient and helpful method for excavating elite rice strains for breeding [36]. After further confirmation, InDel markers and a KASP marker were successfully developed for cabbage lines carrying BoHL1 and BoHL2, respectively, which were the first marker set designed to detect HL in cabbage.

\subsection{Prospect of Preventing Hybrid Lethality}

HL hinders gene exchange between different species and limits heterosis exploitation among certain elite parental lines. We have encountered several cases of hybrid lethality in our cabbage breeding work, resulting in direct economic losses. In our study, 12 hybrid lethal cabbage lines were identified by using molecular markers, and this large number exceeded our expectations. Therefore, the development of the user-friendly molecular markers MBoHL1 and KBoHL2 was a necessary step for identifying all cabbage lines carrying HL genes and will help us avoid hybrid lethal combinations in breeding. In addition, further molecular and functional analyses of HL in cabbage will advance our understanding of the molecular mechanisms underlying HL. Additionally, alternative methods might be adopted to prevent HL and avoid extra economic losses, including: (1) Blockage of the key genes or pathways involved in HL. Rubén et al. (2009) reported that salicylic acid (SA) pathway activation is necessary for HL and that overexpression of the salicylate hydroxylase gene $(\mathrm{NahG}$ ) rescues phenotypic cell death [37]. (2) High-temperature environment. High temperature inhibits the death of HL seedlings in cotton [38]. (3) Exogenous hormone treatment. Nicotiana glutinosa $\times N$. repanda exhibits temperature-sensitive HL with a higher auxin (AUX) content, and exogenous AUX treatment prevents death [39]. (4) $\gamma$-ray and ion beam irradiation [40-42].

\section{Conclusions}

In our study, 54 previous mapping markers were closely linked to BoHL1 or BoHL2, and only six markers for BoHL2 were available when examined in eight cabbage lines (two BoHL1 lines; three BoHL2 lines; three lines without BoHL); however, they were neither universal nor user-friendly when employed for HL identification in more inbred lines. Then, an InDel in BoHL1 and an SNP in BoHL2 were identified, and the corresponding InDel marker MBoHL1 and the KASP marker KBoHL2 were developed and showed 100\% accuracy in eight inbred lines. Moreover, one inbred line carrying BoHL1 and 11 inbred lines carrying BoHL2 were identified from 138 cabbage inbred lines using the two diagnostic markers. All of the lethal plant genotypes obtained with the two markers matched the phenotype, which was further validated by the crossing results, indicating that the two markers were highly reliable for the rapid identification of HL genes in cabbage.

Supplementary Materials: The following are available online at https:/ /www.mdpi.com/article/10 .3390 /agronomy11050982/s1, Table S1 Nucleotide variations in group 1 in the BoHL1 region. Table S2 Nucleotide variations in group 2 near the BoHL2 region. Table S3 List of cross combinations and genotypes. Table S4 Genotype plot for 138 cabbage lines evaluated in this study.

Author Contributions: Z.X. performed the experiments and wrote the manuscript. H.L. and Z.F. conceived the study and edited the manuscript. C.K., F.H. analyzed the data and created the figures and tables. L.Y., M.Z., Y.Z., Y.W., J.J. and Z.L. coordinated the study. All authors have read and agreed to the published version of the manuscript.

Funding: This study was supported by grants from the National Natural Science Foundation of China (31572139), the Science and Technology Innovation Program of the Chinese Academy of 
Agricultural Sciences (CAAS-ASTIP-IVFCAAS) and the earmarked fund for the Modern AgroIndustry Technology Research System, China (CARS-23).

Institutional Review Board Statement: Not applicable.

Informed Consent Statement: Not applicable.

Data Availability Statement: No new data were created or analyzed in this study. Data sharing is not applicable to this article.

Acknowledgments: The work was performed at the Key Laboratory of Biology and Genetic Improvement of Horticultural Crops, Ministry of Agriculture, Beijing 100081, China.

Conflicts of Interest: The authors declare no conflict of interest.

\section{References}

1. Fang, Z.; Sun, P.; Liu, Y.; Yang, L.; Wang, X.; Hou, A.; Bian, C. A male sterile line with dominant gene (Ms) in cabbage (Brassica oleracea var. capitata) and its utilization for hybrid seed production. Euphytica 1997, 97, 265-268. [CrossRef]

2. Lv, H.; Fang, Z.; Yang, L.; Zhang, Y.; Wang, Y. An update on the arsenal: Mining resistance genes for disease management of brassica crops in the genomic era. Hortic. Res. 2020, 7, 34. [CrossRef] [PubMed]

3. Parkash, C.; Verma, T.; Kumar, P. Genetic analysis of cabbage (Brassica oleracea var capitata) using self-incompatible lines. Indian J. Agric. Sci. 2003, 73, 412-413.

4. Singh, K.; Jindal, V.; Singh, V.; Pankaj, R. Performance of Bt cotton hybrids under different geometrical arrangements. J. Cotton Res. Dev. 2007, 21, 41-44.

5. Umakanth, A.; Madhusudhana, R.; Latha, K.; Kaul, S. Heterosis studies for yield and its components in rabi sorghum [Sorghum bicolor (L.) Moench.]. Indian J. Genet. Plant Br. 2003, 63, 2.

6. Von Meyer, W. Maize Plant Having Increased Seed Yield Through Recessive Genetic Determinants That Confer Expanded Corn Ear Tips. U.S. Patent US20080152144, 13 May 2008.

7. Makanda, I.; Tongoona, P.; Derera, J. Combining ability and heterosis of sorghum germplasm for stem sugar traits under off-season conditions in tropical lowland environments. Field Crop. Res. 2009, 114, 272-279. [CrossRef]

8. Troyer, A.F. Adaptedness and heterosis in corn and mule hybrids. Crop. Sci. 2006, 46, 528-543. [CrossRef]

9. Virmani, S.; Aquino, R.; Khush, G. Heterosis breeding in rice (Oryza sativa L.). Theor. Appl. Genet. 1982, 63, 373-380. [CrossRef]

10. Hui, L.; Jiye, Y.; Mei, W.; Zhanpin, H.; Lihong, L.; Hanmin, J.; Jia, Y.; Xue, H.; Min, L.; Sun, D. Transcriptome and DNA methylome reveal insights into yield heterosis in the curds of broccoli (Brassica oleracea L var. italic). BMC. Plant Biol. 2018, $18,168$.

11. Hollingshead, L. Lethal factor in Crepis effective only in an interspecific hybrid. Genetics 1929, 15, 114-140. [CrossRef]

12. Wiebe, G. Complementary factors in barley giving a lethal progeny. J. Hered. 1934, 25, 273-274. [CrossRef]

13. Shii, C.; Mok, T.; Temple, S.; Mok, D. Expression of developmental abnormalities in hybrids of Phaseolus vulgaris L. Interaction between temperature and allelic dosage. J. Hered. 1980, 71, 219-222. [CrossRef]

14. Chen, C.; Chen, H.; Lin, Y.; Shen, J.; Shan, J.; Qi, P.; Shi, M.; Zhu, M.; Huang, X.; Feng, Q.; et al. A two-locus interaction causes interspecific hybrid weakness in rice. Nat. Commun. 2011, 5, 3357. [CrossRef] [PubMed]

15. Bomblies, K.; Lempe, P.; Epple, N.; Warthmann, C.; Lanz, J.; Dangl, L.; Weigel, D. Autoimmune response as a mechanism for a Dobzhansky-Muller-type incompatibility syndrome in plants. PLoS Biol. 2007, 5, 1962-1972. [CrossRef]

16. Jeuken, M.; Zhang, N.; McHale, L.; Pelgrom, K.; Lindhout, B.; Michelmore, R.; Vissera, R.; Niksa, R. Rin4 causes hybrid necrosis and race-specific resistance in an interspecific lettuce hybrid. Plant Cell 2009, 21, 3368-3378. [CrossRef] [PubMed]

17. Chae, E.; Bomblie, K.; Kim, S.; Karelin, D.; Zaidem, M.; Ossowski, S.; Martín-Pizarro, C.; Laitinen, R.; Rowan, B.; Tenenboim, H.; et al. Species-wide genetic incompatibility analysis identifies immune genes as hot spots of deleterious epistasis. Cell 2014, 159, 1341-1351. [CrossRef]

18. Zuellig, M.; Sweigart, A.; Malik, H. Gene duplicates cause hybrid lethality between sympatric species of Mimulus. PLoS Genet. 2018, 12, 14. [CrossRef]

19. Hu, Y.; Xue, Y.; Liu, J.; Fang, Z.; Yang, L.; Zhang, Y.; Liu, Y.; Li, Z.; Zhuang, M. Hybrid lethality caused by two complementary dominant genes in cabbage (Brassica oleracea L.). Mol. Breed. 2016, 36, 73. [CrossRef]

20. Orr, H.; Coyne, J. The genetics of adaptation: A reassessment. Am. Nat. 1992, 140, 725-742. [CrossRef]

21. Forsdyke, D.R. Regions of relative GC\% uniformity are recombinational isolators. J. Biol. Syst. 2004, 12, 261-271. [CrossRef]

22. Williams, J.; Hanafey, M.; Rafalski, J.; Tingey, S. Genetic analysis using random amplified polymorphic DNA (RAPD) markers. Method Enzymol. 1993, 218, 704-740.

23. Aveskamp, M.; Woudenberg, J.; Gruyter, J.; Turco, E.; Groenewald, J.; Crous, P. Development of taxon-specific sequence characterized amplified region (SCAR) markers based on actin sequences and DNA amplification fingerprinting (DNF): A case study in the Phoma exigua species complex. Mol. Plant Pathol. 2010, 10, 403-414. [CrossRef] [PubMed]

24. Charters, Y.; Robertson, A.; Wilkinson, M.; Ramsay, G. PCR analysis of oilseed rape cultivars (Brassica napus L. ssp. oleifera) using 5'-anchored simple sequence repeat (SSR) primers. Theor. Appl. Genet. 1996, 92, 442-447. [CrossRef] [PubMed] 
25. Lv, H.; Yang, L.; Kang, J.; Wang, Q.; Wang, X.; Fang, Z.; Liu, Y.; Zhuang, M.; Zhang, Y.; Lin, Y.; et al. Development of InDel markers linked to Fusarium wilt resistance in cabbage. Mol. Breed. 2013, 32, 961-967. [CrossRef]

26. Liu, X.; Han, F.; Kong, C.; Fang, Z.; Yang, L.; Zhang, Y.; Zhuang, M.; Liu, Y.; Li, Z. Rapid introgression of the Fusarium Wilt Resistance gene into an elite cabbage line through the combined application of a microspore culture, genome background analysis, and disease resistance-specific marker assisted foreground selection. Front. Plant Sci. 2017, 8, 354. [CrossRef] [PubMed]

27. Xiao, Z.; Han, F.; Hu, Y.; Xue, Y.; Fang, Z.; Yang, L.; Zhang, Y.; Li, Z.; Wang, Y.; Zhuang, M. Overcoming cabbage crossing incompatibility by the development and application of self-compatibility-QTL-specific markers and genome-wide background analysis. Front. Plant Sci. 2019, 10, 189. [CrossRef]

28. Yu, H.; Fang, Z.; Liu, Y.; Yang, L.; Zhuang, M.; Lv, H.; Li, Z.; Han, F.; Liu, X.; Zhang, Y. Development of a novel allele-specific Rfo marker and creation of Ogura CMS fertility-restored interspecific hybrids in Brassica oleracea. Theor. Appl. Genet. 2016, 129, 1625-1637. [CrossRef]

29. Yu, H.; Li, Z.; Yang, L.; Liu, L.; Zhuang, M.; Zhang, L.; Lv, H.; Li, Z.; Han, F.; Liu, X. Morphological and molecular characterization of the second backcross progenies of Ogu-CMS Chinese kale and rapeseed. Euphytica 2017, 213, 55. [CrossRef]

30. Han, F.; Zhang, X.; Yuan, K.; Fang, Z.; Yang, L.; Zhuang, M.; Zhang, Y.; Wang, Y.; Liu, Y.; Li, Z.; et al. A user-friendly KASP molecular marker developed for the DGMS-based breeding system in Brassica oleracea species. Mol. Breed. 2019, 39, 90. [CrossRef]

31. Wang, X.W.; Fang, Z.Y.; Sun, P.T.; Liu, Y.M.; Yang, L.M.; Zhuang, M. A SCAR marker applicable in marker assisted selection of a dominant male sterility gene in cabbage. Acta Hortic. Sin. 2000, 27, 143-144.

32. Xiao, Z.; Hu, Y.; Zhang, X.; Xue, Y.; Fang, Z.; Yang, L.; Zhang, Y.; Liu, Y.; Li, Z.; Liu, X.; et al. Fine mapping and transcriptome analysis reveal candidate genes associated with hybrid lethality in cabbage (Brassica oleracea). Genes 2017, 8, 2-17.

33. Han, F.; Zhang, X.; Liu, X.; Su, H.; Kong, C.; Fang, Z.; Yang, L.; Zhuang, M.; Zhang, Y.; Liu, Y.; et al. Comparative analysis of genome wide DNA methylation profiles for the genic male sterile cabbage line 01-20S and its maintainer line. Genes 2017, 8, 159. [CrossRef] [PubMed]

34. Naeela, Q.; Pakeerathan, K.; Kebede, G.; Vallence, N.; Vanessa, W.; Prashanth, B.; Debbie, W.; Matthew, H.; Harbans, B.; Urmil, B. Development of co-dominant KASP markers co-segregating with Ug99 effective stem rust resistance gene Sr26 in wheat. Mol. Breed. 2018, 38, 97.

35. Yang, G.; Chen, S.; Chen, L.; Gao, W.; Huang, Y.; Huang, C.; Huang, C.; Zhou, D.; Wang, J.; Liu, Y.; et al. Development and utilization of functional KASP markers to improve rice eating and cooking quality through mas breeding. Euphytica 2019, 215, 66. [CrossRef]

36. Yang, G.; Chen, S.; Chen, L.; Sun, K.; Guo, T. Development of a core SNP arrays based on the KASP method for molecular breeding of rice. Rice 2019, 12, 1-18. [CrossRef]

37. Ruben, A.; García, A.; Parker, J.; Reymond, M. Incremental steps toward incompatibility revealed by arabidopsis epistatic interactions modulating salicylic acid pathway activation. Proc. Natl. Acad. Sci. USA 2009, 106, 334-339.

38. Tezuka, T.; Marubashi, W. Genomic factors lead to programmed cell death during hybrid lethality in interspecific hybrids between Nicotiana tabacum and N. debneyi. Sabrao. J. Breed. Genet 2006, 38, 69-81.

39. Tetsuya, Y.; Wataru, M.; Teruko, N.; Masaru, N. Possible involvement of auxin-induced ethylene in an apoptotic cell death during temperature-sensitive lethality expressed by hybrid between Nicotiana glutinosa and N. repanda. Plant Cell Physiol. 2001, 9, 923-930.

40. Shintaku, Y.; Yamamoto, K.; Nakajima, T. Interspecific hybridization between Nicotiana repanda Willd and N. tabacum L. through the pollen irradiation technique and the egg cell irradiation technique. Theor. Appl. Genet. 1988, 76, 293-298. [CrossRef]

41. Tanaka, S. Chromosomal rearrangements in interspecific hybrids between Nicotiana gossei Domin and N. tabacum L., obtained by crossing with pollen exposed to helium ion beams orgamma-rays. Nucl. Instruments. Meth. B 2003, 206, 548-552.

42. Sharma, D. Use of radiations for breaking hybrid necrosis in wheat. Euphytica 1969, 18, 66-70. 